\title{
The conservation status of bats in Fiji
}

\author{
Annette Scanlon, Sophie Petit and Guy Bottroff
}

\begin{abstract}
Bats provide important ecosystem services throughout the South Pacific but many species are threatened. The Fiji archipelago has a rich bat fauna yet few arrangements exist to promote the conservation of this group. From July 2008 to March 2011 we visited important sites identified in previous surveys for bats on Vanua Levu, Taveuni, Viti Levu and the Yasawa Islands. We netted and recorded five of Fiji's six bat species (Pteropus tonganus, Pteropus samoensis nawaiensis, Notopteris macdonaldi, Chaerephon bregullae and the Critically Endangered Mirimiri acrodonta). This was only the sixth recorded capture of M. acrodonta. P. tonganus is widespread in Fiji and exploits many different environments. P. samoensis nawaiensis mostly uses forested areas, and large tracts of forest are required for its long-term protection. Cave protection is vital for the two insectivorous species (C. bregullae and Emballonura semicaudata) and N. macdonaldi. In particular, the Nakanacagi maternity site remains globally significant for C. bregullae. E. semicaudata was not caught or detected during our surveys. It appears to be extinct from most large islands in Fiji and has abandoned the only large cave roost (Yaqeta) observed 10 years ago. This species has disappeared from or declined dramatically on Vanuatu, Samoa, Tonga and Fiji. We recommend that the category of E. semicaudata semicaudata on the IUCN Red List be changed to Critically Endangered. Management priorities should focus on community engagement and education, and improved cave and forest management and protection.
\end{abstract}

Keywords Cave management, bats, Chiroptera, cyclone, Emballonuridae, Fiji, Molossidae, Pteropodidae

This paper contains supplementary material that can be found online at http://journals.cambridge.org

\section{Introduction}

Cerious population declines and/or extinctions of the $\checkmark$ bat fauna of the Pacific Islands have been recorded since 1970 (Wodzicki \& Felten, 1975, 1980; Wiles, 1987; Falanruw, 1988; Craig et al., 1994; Grant et al., 1994; Flannery, 1995; Koopman \& Steadman, 1995; Tarburton, 2002; Palmeirim

\footnotetext{
Annette Scanlon (Corresponding author), Sophie Petit and Guy BottrofF Sustainable Environments Research Group, School of Natural and Built Environments, University of South Australia, Mawson Lakes SA 5095, Australia. E-mail Scanlonannette@gmail.com

Received 9 July 2012. Revision requested 19 October 2012.

Accepted 16 November 2012. First published online 11 October 2013.
}

et al., 2007). Island nations have a disproportionately large role to play in global bat conservation because many threatened bat species are found only on islands (Mickleburgh et al., 2002). Mickleburgh et al. (2002) found that 17 of 29 Critically Endangered bat species occurred on islands (Comoros, Federated States of Micronesia, Japan, Madagascar, Mauritius, Papua New Guinea, Philippines, Seychelles, Solomons and Fiji). Fiji has a relatively high diversity of bats (Mickleburgh et al., 1992). They are the only mammals native to these islands and throughout much of the South Pacific, where they are important for pollination and seed dispersal (Cox et al., 1991, 1992; McConkey \& Drake 2002, 2006; Fujita \& Tuttle, 1991). Few arrangements exist for the protection of the bats of Fiji, however. The first detailed conservation assessment was in 1990-1991 (Ingleby \& Flannery, 1991; Flannery, 1995) and the second in 2000-2001 (Palmeirim et al., 2005, 2007). We studied the bats of Fiji from July 2008 to March 2011, collecting data from captures and cave explorations and visiting key sites identified by previous surveys. Our research incorporates observations made before and after tropical cyclone Tomas. We aimed to (1) use netting to elucidate the use of forest habitats by bats, with a particular focus on Mirimiri acrodonta, a species not recorded for 20 years, (2) re-evaluate the conservation status of the bats of Fiji, and (3) assess the impacts of the cyclone on bats.

\section{Methods}

Fiji has four plant-visiting and two insectivorous bat species. The Pteropodidae (Old World plant-visiting bats) are $M$. acrodonta (synonym Pteralopex acrodonta; Helgen, 2005; endemic to Fiji; Critically Endangered), Pteropus samoensis nawaiensis (endemic subspecies; P. samoensis is categorized as Near Threatened), Notopteris macdonaldi (Fiji and Vanuatu; Vulnerable), and the widespread subspecies Pteropus tonganus tonganus (Fiji, Samoa, Tonga and Cook Islands; Least Concern; Flannery, 1995; IUCN, 2012a). The insectivorous Chaerephon bregullae (synonym Tadarida bregullae, Molossidae; Endangered) is endemic to Fiji and Vanuatu, and Emballonura semicaudata (Emballonuridae; Endangered) is widely distributed (IUCN, 2012a); the subspecies E. semicaudata semicaudata has been recorded on Fiji, Samoa, Tonga and Vanuatu (Flannery, 1995; Koopman, 1997; Helgen \& Flannery, 2002).

We used Anabat technology (Titley Scientific, Australia) for bat detection. We netted and recorded bats on Vanua Levu and Taveuni and explored caves on Vanua Levu, Viti Levu and Yaqeta (Yasawa) during 2008-2011 (Fig. 1). 


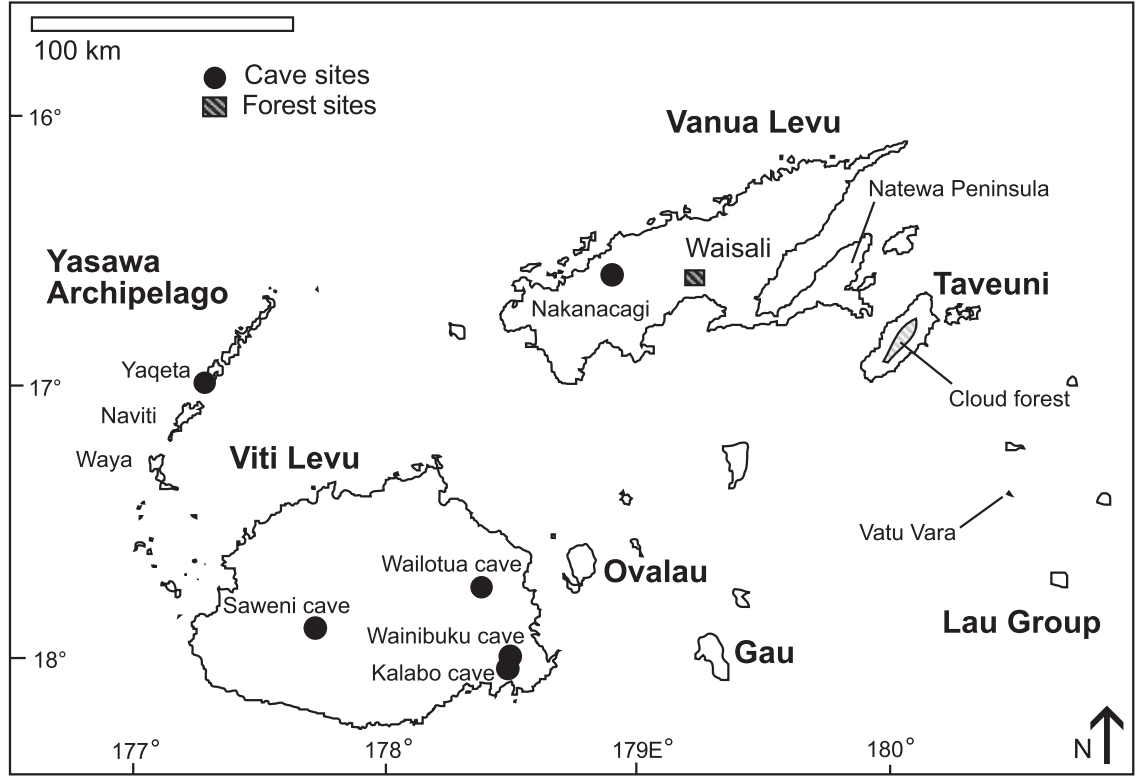

FIG. 1 The study sites in Fiji: netting occurred in forested areas on Vanua Levu and Taveuni and in caves on Vanua Levu, Viti Levu and Yaqeta (Yasawa).
On Vanua Levu we surveyed in lowland and upland tropical rainforest (50-650 $\mathrm{m}$ altitude) in the Waisali catchment and ridge-top forests of the main mountain range, on land owned by the Mataqali Waisali clan (Wailevu, Cakaudrove Province). The area contains some of the last unexploited rainforest on Vanua Levu (Tuiwawa, 1999) and the forest has been identified as a high priority for conservation in Fiji (Olson et al., 2009). The second netting location, in upland stunted cloud forest (800-1,200 m) near Des Voeux Peak, Taveuni, is the only known habitat of M. acrodonta (Hill \& Beckon, 1978; Flannery, 1995; Scanlon, 2009a) and has also been identified as a high priority for conservation. The area is rich in large epiphytes growing in the canopy of dominant trees. All other Fijian bat species have been recorded here except E. semicaudata (Ingleby \& Flannery, 1991), which occurs at sea level on the same island (Palmeirim et al., 2007; Macedru, 2010).

We used nylon mist nets to capture bats, and standardized the number of mist-net-hours ( $\mathrm{mnh}$ ) as in Kalko \& Handley (2001). We completed 1,887 mnh near Des Voeux Peak in April, May, June, August and November 2009. Near Waisali we completed 2,553 mnh over 22 months (total $=4,440 \mathrm{mnh})$. We recorded species, mass, forearm length, gender and reproductive status. Young bats were distinguished via inspection of cartilaginous epiphyseal growth (Brunet-Rossinni \& Wilkinson, 2009) and by size. All bats except for insectivorous bats or juvenile N. macdonaldi (mass $<20 \mathrm{~g}$ ) were tagged with $11-\mathrm{mm}$ passive integrated transponders (Allflex, Brisbane, Australia), injected subcutaneously between the scapulae. Plant-visiting bats were fed apricot nectar prior to release at the capture site, to compensate for loss of feeding time.

We also conducted cave surveys, accompanied by local guides, for N. macdonaldi and both insectivorous bat species
(Supplementary Table $\mathrm{S}_{1}$ ). We had discussions with local people, chiefs and the turaga-ni-koro (village spokesperson) at each survey site, and they recommended experienced field guides. We visited four N. macdonaldi cave roosts on Viti Levu (Wailotua, Wainibuku, Kalabo and Saweni; Gilbert, 1984; Flannery, 1995; Palmeirim et al., 2007; Scanlon, 2009b) and Dharam Singh and Udit, near Kalabo. We also checked these caves for E. semicaudata, which may be extinct from Viti Levu (Flannery, 1995) but was recorded at these sites in the 1960s and 1970s (Watling \& Pernetta, 1978; Gilbert, 1984). On Vanua Levu we visited a large mudstone cave near Nakanacagi (an important maternity site for C. bregullae) in 2010 and 2011. We searched for E. semicaudata on coastal overhangs and in caves along Savusavu Bay, in a limestone cave within Namale Resort, on a large limestone outcrop near Savusavu airport and on many rocky outcrops and in small caves across Waisali land. This species is considered rare on Vanua Levu (Palmeirim et al., 2007). We also visited Waya, Naviti and Yaqeta Islands in the Yasawa archipelago. The Yaqeta Island cave was identified as a key site for E. semicaudata by Palmeirim et al. $(2005,2007)$, and we visited the site with a local guide who had participated in the 2000-2001 survey. Like Palmeirim et al. (2005, 2007), we were unable to visit Vatu Vara to confirm the presence of a second large colony of E. semicaudata. We estimated population size visually at each cave. We located dense groups of bats (N. macdonaldi and C. bregullae) within each cave, counted a sub-sample occupying a small area, and then multiplied that figure by the total area occupied by bats.

Tropical cyclone Tomas (9-18 March 2010; Category 4) tracked over Vanua Levu and Taveuni on 15-16 March, then moved south through the Lau Group. We conducted monthly netting sessions before ( $\mathrm{n}=13$ months) and after ( $\mathrm{n}=9$ months) the cyclone on Vanua Levu. We compared 
monthly capture rates (bats per mnh) of the most commonly netted species, $N$. macdonaldi, before and after the cyclone, with a $t$-test, and made opportunistic observations of Pteropus spp. in a rural garden during January-July 2010. Diurnal behaviours were observed using binoculars and a spotting scope.

\section{Results}

We netted 293 bats of five species (M. acrodonta, P. tonganus, P. samoensis nawaiensis, N. macdonaldi and C. bregullae) on Vanua Levu ( $\mathrm{n}=252$, four species) and Taveuni $(\mathrm{n}=41$, five species) during 2008-2011. Additionally, we measured six C. bregullae from Nakanacagi cave and one P. tonganus that was killed by villagers. As expected, M. acrodonta was only recorded at Des Voeux Peak. One individual was netted at $815 \mathrm{~m}$; on release it flew to the canopy of a nearby tree ( $>15 \mathrm{~m}$, Palaquium sp.; Sapotaceae) and crawled into a large clump of epiphytes. Upon inspection via abseiling, the tree showed no evidence of regular use by bats (no odour or signs of nesting; Scanlon, 2009a). P. tonganus, P. samoensis nawaiensis, N. macdonaldi and C. bregullae were captured on both Vanua Levu and Taveuni. C. bregullae used flat echolocation calls between 20 and $35 \mathrm{kHz}$.

Reproduction schedules varied among species. We caught pregnant $C$. bregullae (two of three females captured) in November on Taveuni. The M. acrodonta individual captured in May was pregnant, which accounts for its increased mass compared with the lactating individuals caught in 1990-1991 (Flannery, 1995; Supplementary Table $\mathrm{S}_{1}$ ). N. macdonaldi and $P$. samoensis nawaiensis reproduced year-round, and $P$. tonganus formed annual maternity camps in July-September (2009 and 2010). E. semicaudata was the only species we did not encounter (32 detector-nights: four on Taveuni, 28 at Waisali). As expected, E. semicaudata appears to be extinct on Viti Levu; it has not been recorded there for $>20$ years. Neither was this species found in any cave or coastal overhang on Vanua Levu. Furthermore, the most important cave colony, recorded by Palmeirim et al. (2007) on Yaqeta Island, was deserted and there was no evidence of recent use by bats (odour, fresh guano). The vandalized cave is located within a small fragment of forest frequented by goats (Plate 1 ).

We found similar numbers of N. macdonaldi at Kalabo, Wainibuku, Wailotua and Saweni (Viti Levu) to those estimated in 2000-2001 (Palmeirim et al., 2005, 2007). We estimated 1,000-2,000 roosting bats in each of Kalabo, Wainibuku and Wailotua (Scanlon, 2009b). In 2009 we counted bats during the evening fly-out at Saweni; we estimated c. 200 bats, matching our 2008 estimate of the number of roosting bats inside the cave. At Saweni, bats gathered near the cave entrance at dusk, vocalizing and moving about before leaving singly after sunset. Some $N$. macdonaldi $(\mathrm{n}=22)$ were netted at Waisali shortly after

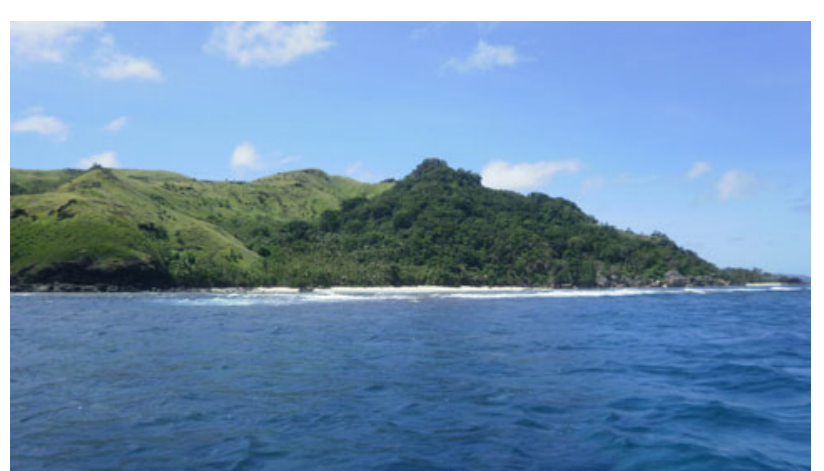

Plate 1 Yaqeta Island, where deforestation is widespread. The surveyed cave lies within a small remnant of forest but has been vandalized.

dusk but no roost was found nearby. At Nakanacagi cave we estimated c. 2,000 C. bregullae, with similar numbers in 2010 and 2011. Palmeirim et al. (2005) reported native forest nearby, but we found the cave within disturbed forest, with agricultural land use and a timber mill nearby. We found nets and poles in the cave. According to our guides harvesting of bats is rare, but several bags of $50 \mathrm{~kg}$ capacity may be filled during a single harvest.

Large P. tonganus camps (from 300 to several thousand) occur throughout Fiji; we observed them in the Yasawas, on Taveuni and throughout Vanua Levu and Viti Levu, in forested, coastal and urban areas (Supplementary Table S1). This species was harvested in most rural villages that we visited ( $>30$ villages) but often in low numbers and mostly opportunistically (for example only one bat was killed in Waisali village in 2009). P. samoensis nawaiensis was known to many villagers and was identified as a smaller, light-coloured ('beka lulu' = white bat) forest species with a strong odour. P. samoensis nawaiensis was said to be eaten only occasionally because of its unpleasant odour. At Waisali two animals were captured 2 weeks after cyclone Tomas. The increased capture rate of bats in villages after cyclones was reported by several villagers throughout Fiji; they mentioned that bats were less cautious and came to forage close to and sometimes on the ground.

Prior to the cyclone (January-March 2010) P. samoensis nawaiensis was not observed diurnally in garden and urban areas near Savusavu, but it was observed frequently in such areas in the weeks after, feeding on garden fruits (breadfruit, banana and pawpaw) at dusk, possibly indicating loss of forest resources. During this time (16-30 March 2010) $P$. samoensis nawaiensis competed with the larger P. tonganus for the fruits ( $>10$ confrontations observed); $P$. tonganus, which uses the resource year-round (authors, pers. obs.), seemed to win most confrontations. No Pteropus sp. was caught during a netting survey 9 days after the cyclone in Waisali forest. These large bats were caught irregularly, so any potential change as a result of the cyclone could not be examined statistically. However, fewer 
N. macdonaldi were caught after the cyclone (monthly mean $\pm \mathrm{SE}=0.02 \pm 0.007$ bats per mnh, $\mathrm{n}=9$ months) than before (monthly mean $\pm \mathrm{SE}=0.11 \pm 0.019$ bats per mnh, $\mathrm{n}=13$ months; $t=3.492, \mathrm{df}=20, \mathrm{P}=0.002$ ).

\section{Discussion}

Our re-evaluation of the conservation status for each species is based on a survey of a limited area of Fiji. However, there are several indications that bats may be increasingly threatened. Older people in the community mentioned that they used to see a lot of bats of different species, and many caves that used to contain bats no longer host any. The main threats to frugivorous bats are likely to be habitat loss (P. samoensis nawaiensis, M. acrodonta) and the poor condition of caves (N. macdonaldi); insectivorous bats face the same threats, in addition to hunting. Revisiting key sites identified by Flannery (1995) and Palmeirim et al. $(2005,2007)$ has led to a proposed change of status for E. semicaudata semicaudata.

\section{Pteropus samoensis nawaiensis}

P. samoensis nawaiensis uses lowland and upland rainforest (Vanua Levu) and cloud forest (Taveuni) in Fiji. Our observations of roosting and territorial behaviours in secondary rainforest indicate that disturbed forests are also valuable. Territorial behaviour is similar to that observed in Samoa (Brooke, 2001). P. samoensis nawaiensis is most active nocturnally (diurnal activity has been reported for P. samoensis samoensis in Samoa, Cox, 1983; Wilson \& Engbring, 1992). Because P. samoensis prefers forest habitat (Brooke et al., 2000; Brooke, 2001; Palmeirim et al., 2005, 2007) and cyclones can cause immense damage to forests in the Pacific (Elmqvist et al., 1994; Burslem et al., 2000; Franklin et al., 2004) and reduce the abundance of fruit bat species (Craig et al., 1994; Pierson et al., 1996; Jones et al., 2001; McConkey et al., 2004), sufficient areas of forest need to be protected (Pierson et al., 1996) to safeguard this species against long-term decline. This species was recategorized from Vulnerable to Near Threatened in 1996 because of the recovery of Samoan populations (Brooke \& Wiles, 2008).

\section{Pteropus tonganus}

This species forms large raucous colonies and we observed it using mangroves, lowland and cloud forest areas, small islets and large islands, as well as agricultural and urban environments. It is often considered a pest because it consumes garden fruits, and local communities are unaware of its role in pollination and seed dispersal. It is regularly caught for consumption but only in small numbers.
Many local people with whom we spoke assumed that bats are common in Fiji because of their observations of $P$. tonganus. Relative to other species, $P$. tonganus has been well studied (Wodzicki \& Felten, 1975; Cox, 1983; Wilson \& Graham, 1992; Craig et al., 1994; Pierson et al., 1996; Grant et al., 1997; Brooke et al., 2000; Brooke \& Tschapka, 2002; McConkey et al., 2004; Cousins \& Compton, 2005). Harvesting at the current rate does not seem to threaten the species in Fiji (Palmeirim et al., 2007). However, in October 2012 an urban dweller in Savusavu told us that he ate a bat ( $P$. tonganus) at least once per month to combat his asthma. If bats are believed to have curative properties they will be used by a broader section of the community.

\section{Mirimiri acrodonta}

M. acrodonta is poorly known by local people and the scientific and conservation community. We observed this species taking refuge in epiphytic clumps in cloud forest canopy. We did not set nets in cloud forest near Delaikoro on Vanua Levu, where this species may occur (suggested by P. German in Flannery, 1995 and pers. comm.); however, we set nets in semi-montane ridge-top forests $(650 \mathrm{~m})$ on Vanua Levu and did not encounter the species. The rewards for net effort are poor and few studies have focused on this species (we netted one individual in 1,887 mnh). The species' closest relatives (three Pteralopex species from the Solomon Islands; Flannery, 1991, 1995) are also Critically Endangered (Mickleburgh et al., 2002) and are difficult to net (Flannery 1991). The biggest threats to M. acrodonta are habitat loss, degradation, fragmentation (via cyclones, agricultural and urban development, encroachment, and pollution; Ash, 1992; authors, pers. obs.), and alteration via climate change (Still et al., 1999). LaVal (2004) attributed the movement of lowland bat species into Costa Rican tropical cloud forest to global warming, forest clearing and increased secondary forest. Changes to the microclimate of Taveuni cloud forest could preclude species on which $M$. acrodonta relies (e.g. for food and shelter) and result in increased movement of lowland species into the area, potentially increasing competition with other pteropids. Cyclone Tomas passed directly over Taveuni and forest resources were undoubtedly depleted after the cyclone. The timing of the cyclone, near the May breeding period, may have been devastating for bats with increasing energy requirements (i.e. pregnant and lactating) and severe habitat constraints (restricted to mountain-top cloud forest). A captive-breeding programme is highly desirable for this species (Palmeirim et al., 2007). Future research should include long-term monitoring of the Taveuni cloud forest microclimate and vegetation phenology surveys to identify potential food plants, with a focus on the resources available during the May breeding period. 


\section{Notopteris macdonaldi}

Commonly known as the blossom bat, N. macdonald $i$ has an important role in pollinating rainforest plants, but this role is poorly understood and should be elucidated for management and education purposes. We found most knowledge of this species in villages near its roosting caves. A fifth cave harbouring a population of $N$. macdonald $i$ was documented by NatureFiji-MareqetiViti (2012) near Nabukelevu in the Serua highlands, Viti Levu. The caves are not protected and most are threatened by pollution and agriculture, and bats are disrupted by noise and vibrations from a nearby quarry (Scanlon, 2009b). Nearly half of the five known caves occur within suburban areas of Suva. The fact that bats persist at Kalabo and Wainibuku is testament to their ability to tolerate some disturbance but could indicate the paucity of suitable alternatives. Proximity to urban areas presents an opportunity for public involvement in education, and management and restoration of caves. Forests are also crucial for $N$. macdonaldi, and cyclones result in fewer captures, possibly because of a reduction in available resources.

\section{Chaerephon bregullae}

We found that the insectivorous C. bregullae uses Waisali forests and coastal habitats near Savusavu (Vanua Levu), and we netted it on the edges of cloud forest on Taveuni $(850 \mathrm{~m})$. It was previously netted at Des Voeux Peak (Ingleby \& Flannery, 1991). Our population estimate of c. 2,000 at Nakanacagi is less than the estimate of 'several thousand' by Palmeirim et al. (2007). This discrepancy could be linked to a reduction in forest resources in the area, but the surveys cannot be compared because they were carried out at different times of the year and were visual estimates only. The entire Fijian population of C. bregullae relies on the Nakanacagi breeding cave (Flannery, 1995; Palmeirim et al., 2007; this study). This cave needs immediate protection and meaningful community engagement to reduce harvesting and promote knowledge of the species. The NGO NatureFiji-MareqetiViti is working to engage the local community and increase awareness of the species (Macedru \& Moce, 2011). No recent assessment of the status of the species in Vanuatu has occurred.

\section{Emballonura semicaudata semicaudata}

Patterns of rapid decline of E. semicaudata recorded elsewhere in the Pacific (Perez, 1972; Lemke, 1986; Grant et al., 1994; Flannery, 1995; Tarburton, 2002) are mirrored in Fiji. We heard similar anecdotes to those reported previously (Flannery, 1995; Palmeirim et al., 2005; Macedru \& Moce, 2011); guides familiar with E. semicaudata semicaudata recalled that it was once commonly seen in villages and gardens at dusk and that it formerly roosted in local caves but is no longer seen. It is absent from most large inland caves in Fiji (Flannery, 1995; Palmeirim et al., 2007; this study) yet it prefers large caves elsewhere (Mariana Islands; Wiles et al., 2011). Records show that E. semicaudata also uses exposed shallow coastal caves (Grant et al., 1994; Tarburton, 2002). Large congregations are unlikely to be safe in these caves and only small groups of bats have been recorded using such sites (Flannery, 1995; Palmeirim et al., 2007; Macedru, 2010). These numerous and dispersed roosts are difficult to target for management, and bats using these caves are especially vulnerable to the effects of cyclones (Grant et al., 1994; Tarburton, 2002). The cause of the decline is poorly understood, but predation by cats may be partly responsible (Palmeirim et al., 2005). Despite netting surveys, using detectors, visiting caves and talking and exploring with guides, we found no E. semicaudata semicaudata on Vanua Levu and therefore consider that it is probably extinct from the island. We did not visit the remote Natewa Peninsula, where Palmeirim et al. (2005) found several dozen animals in a coastal cave at Leya (Fig. 1). If that population persists, it is likely to have been affected by Cyclone Tomas (Grant et al., 1994; Tarburton, 2002), which passed directly over the area.

Three other taxa are recognized within this species: E. semicaudata rotensis (Mariana Islands), E. semicaudata palauensis (Palau) and E. semicaudata sulcata (Caroline Islands; Koopman, 1997). The populations of E. semicaudata palauensis and E. semicaudata sulcata are reportedly healthy but few recent data are available (Hutson et al., 2001). E. semicaudata rotensis has declined dramatically in the Marianas and is extinct from several islands (Perez, 1972; Lemke, 1986; Hutson et al., 2001). E. semicaudata semicaudata is isolated from the other subspecies (see distribution in Koopman, 1997); geographically intermediate populations probably went extinct before records could be made (Helgen \& Flannery, 2002). Although E. semicaudata is currently categorized as Endangered (IUCN, 2012a), E. semicaudata semicaudata is considered Critically Endangered on large islands in Fiji (Palmeirim et al., 2005). It appears to be extinct from Viti Levu and probably Kadavu and Yasawas, possibly extinct on Vanua Levu and rare on Taveuni (Ingleby \& Flannery, 1991; Flannery, 1995; Palmeirim et al., 2005, 2007; Macedru, 2010; this study). The species prefers native forest on Pohnpei (Caroline Islands, Bruner \& Pratt, 1979), Mariana Islands (Esselstyn et al., 2004; Gorresen et al., 2009) and Fiji (Zug et al., 1988; Palmeirim et al., 2007); however, the majority of Fiji's native forest occurs on the islands on which the bat is no longer found. We found that the only large colony documented by Palmeirim et al. (2007) had disappeared, and the species appears to have retracted entirely from the Yasawa archipelago. The Fijian population appears 
to comprise only small numbers of bats on small and remote islands (Palmeirim et al., 2005).

In light of the loss of the Yaqeta colony we infer a reduction in population size of $\geqslant 80 \%$ over the last 10 years and we recommend that E. semicaudata semicaudata be recategorized as Critically Endangered, based on criteria A2a,c (i.e. from direct observation and estimated, inferred or suspected observation of population size reduction of $\geqslant 80 \%$ over the last 10 years and decline in area of occupancy or extent of occurrence; IUCN, 2012b). This subspecies is considered to be Critically Endangered in American Samoa and Samoa (Hutson et al., 2001); it was not recorded in American Samoa during surveys in 2006 and 2008 (Fraser et al., 2009) and is extinct on Vanuatu (Helgen \& Flannery, 2002). It was not recorded in Tonga during earlier surveys (Rinke, 1991) or during a 10-night acoustic survey in 2007 (six nights on Tongatapu, four nights on 'Eua; M. Pennay, unpubl. data). Pennay describes 'Eua as the place most likely to support E. semicaudata because of the island's large tracts of primary forest and many rocky outcrops and caves but he considers the bat to be extremely rare or extinct from both islands (M. Pennay, pers. comm.).

No captive breeding programme exists for this species and none is likely to occur, given its current conservation status of Endangered, which infers a lower priority than Critically Endangered. However, reasonable opportunities still exist to establish captive populations for insurance against extinction in the wild. Macedru (2010) found $<10$ individuals using two caves on Taveuni (Tavuyaga and Waitabu) and observed one with a pup. Many thousands of E. semicaudata were observed on Rotuma in 1985; bats used a variety of habitats there, including village gardens (Clunie, 1985). However, in 1987 Zug et al. (1988) found the bat only infrequently on Rotuma, observing it singly in or near forest areas. Taveuni, the Lau Group (including Vatu Vara) and Rotuma are important locations for the species and surveys on these islands are highly desirable. Palmeirim et al. (2007) reported evidence of marked declines on Lau. Small groups reported on Ovalau and Gau (Fig. 1; Ingleby \& Flannery, 1991; Palmeirim et al., 2005; K. Macedru, pers. comm.) should be monitored. Regional surveys are needed to update the status of E. semicaudata semicaudata in Samoa and Tonga.

\section{Forest and cave conservation}

All Fijian bats require forest areas in which to feed, breed and retreat from anthropogenic pressures, thus forest protection is imperative to ensure their longevity. Forest degradation, conversion and destruction remain key threats to terrestrial biodiversity in Fiji (Ash, 1992; Lees, 2007). Deforestation may also affect cave health via increased runoff and sedimentation loads (Fritsch, 1993; Douglas, 1996; Costa et al., 2003), which may alter cave architecture and microclimate. Cave protection and management are vital to ensure the survival of $N$. macdonaldi, C. bregullae and E. semicaudata. Cave-obligate bats rely on secure caves in which to roost and reproduce, and they are particularly at risk of population declines as a result of human disturbance (Mohr, 1972; Humphrey \& Kunz, 1976; Tuttle, 1979; McCracken, 1986, 1988; Brown et al., 1993; this study). Bats are faithful to few available caves in Fiji and many caves have become unusable (e.g. in 2009 the entrance to the Dharam Singh cave was overgrown by shrubs and blocked with litter). Some caves present obvious opportunities for conservation (e.g. we recommend that the site at Nakanacagi be the focal point for conserving C. bregullae in Fiji). Other cave habitats present particular challenges for management, such as shallow coastal caves used by E. semicaudata. Terms of reference for conservation guidelines need to encompass a variety of cave types to cover all cave-obligate species. Guidelines should also cover the use of caves as tourist attractions to ensure that developments are sensitive to bats and caves and involve monitoring and education components. A cave management plan for Fiji is needed.

\section{Conclusion}

A variety of bat species, some widespread and abundant and others rare and poorly known, presents a challenging situation for public understanding of bats in Fiji. Some people equate bat conservation with a prohibition on P. tonganus harvesting, for example. Meaningful community engagement and education are required. Forest and cave conservation is vital to ensure the survival of all six bat species. The development of national guidelines for cave management and conservation is urgently needed. Surveys focusing on cave roosts are needed to determine the status of N. macdonaldi and C. bregullae on Vanuatu. Surveys for E. semicaudata are also required and should focus on cave roosts and detection in forests; in Fiji, the islands of Rotuma, Lau, Taveuni, Gau and Ovalau are most likely to harbour this species. Partnerships for establishing captive-breeding programmes for E. semicaudata and M. acrodonta should be investigated. Changing perceptions of bats (e.g. emerging medicinal beliefs) should be explored. We recommend monitoring population trends of bats in Fiji to inform future conservation assessments.

\section{Acknowledgements}

We thank William Aalbersberg, Laura Bergner, Fran Callan, Don Drake, Elizabeth Erasito, Pavel German, Joan Gibbs, Jörg Kretzschmar, Waisale Mataitoga, Kelera Macedru, Kolinio Moce, Alivereti Naikatini, Josefa Ravuso, Terry Reardon, Marika Tuiwawa, Dick Watling, and especially 
the Mataqali Waisali for their assistance. Michael Pennay generously provided survey data from Tonga. We are grateful for support from University of South Australia, University of the South Pacific, Department of Forests (Fiji), National Trust of Fiji, NatureFiji-MareqetiViti, and Telecom Fiji Limited (Des Voeux Peak). We are also grateful to GIZ for providing tree identification books. The project was funded by the Australia \& Pacific Science Foundation, the Cathy Candler Bursary (Australian Federation of University Women), an Australian Postgraduate Award, the Jane Gillooly Memorial Award (Australian Society of Soil Science) and the Critical Ecosystem Partnership Fund (to NatureFiji-MareqetiViti). Research was conducted under Animal Ethics Permit 73/08 IMVS/AHS and Waisali Rainforest Reserve Permit WR/o1.

\section{References}

Ash, J. (1992) Vegetation ecology of Fiji: past, present, and future perspectives. Pacific Science, 46, 111-127.

Brooke, A.P. (2001) Population status and behaviours of the Samoan flying fox (Pteropus samoensis) on Tutuila Island, American Samoa. Journal of Zoology, 254, 309-319.

Brooke, A.P., Solek, C. \& Tualauelei, A. (2000) Roosting behaviour of solitary and colonial flying foxes in American Samoa (Chiroptera: Pteropodidae). Biotropica, 32, 338-350.

BROOKE, A.P. \& TsCHAPKA, M. (2002) Threats from overhunting to the flying fox, Pteropus tonganus, (Chiroptera: Pteropodidae) on Niue Island, South Pacific Ocean. Biological Conservation, 103, 343-348.

Brooke, A. \& Wiles, G. (2008) Pteropus samoensis. In IUCN Red List of Threatened Species v. 2012.1. Http://www.iucnredlist.org [accessed 15 October 2012].

Brown, P., Berry, R. \& Brown, C. (1993) Bats and mines: finding solutions. Bats, 11, 12-13.

Bruner, P.L. \& Pratt, H.D. (1979) Notes on the status and natural history of Micronesian bats. Elapaio, 40, 1-4.

Brunet-Rossinni, A.K. \& Wilkinson, G.S. (2009) Methods for age estimation and the study of senescence in bats. In Ecological and Behavioural Methods for the Study of Bats (eds T.H. Kunz \& S. Parsons), pp. 315-325. Johns Hopkins University Press, Baltimore, USA.

Burslem, D.F.R.P., Whitmore, T.C. \& Brown, G.C. (2000) Shortterm effects of cyclone impact and long-term recovery of tropical rain forest on Kolombangara, Solomon Islands. Journal of Ecology, $88,1063-1078$

Clunie, F. (1985) Notes on the bats and birds of Rotuma. Domodomo, 3, 153-160.

Costa, M.H., Botta, A. \& Cardille, J.A. (2003) Effects of large-scale changes in land cover on the discharge of the Tocantins River, Southeastern Amazonia. Journal of Hydrology, 283, 206-217.

Cousins, J.A. \& Compton, S.G. (2005) The Tongan flying fox Pteropus tonganus: status, public attitudes and conservation in the Cook Islands. Oryx, 39, 196-203.

Cox, P.A. (1983) Observations on the natural history of Samoan bats. Mammalia, 47, 519-523.

Cox, P.A., Elmqvist, T., Pierson, E.D. \& Rainey, W.E. (1991) Flying foxes as strong interactors in South Pacific island ecosystems: a conservation hypothesis. Conservation Biology, $5,448-454$.
Cox, P.A., Elmqvist, T., Pierson, E.D. \& Rainey, W.E. (1992) Flying foxes as pollinators and seed dispersers in Pacific Island ecosystems. In Pacific Island Flying Foxes: Proceedings of an International Conservation Conference (eds D.E. Wilson \& G.L. Graham), pp. 74-101. Biological Report 9o. Fish and Wildlife Service, Washington, USA.

Craig, P., Trail, P.W. \& Morrell, T.E. (1994) The decline of fruit bats in American Samoa due to hurricanes and overhunting. Biological Conservation, 69, 261-266.

Douglas, I. (1996) The impact of land-use changes, especially logging, shifting cultivation, mining and urbanization on sediment yields in humid tropical Southeast Asia: a review with special reference to Borneo. International Association of Hydrological Sciences Publications, 236, 463-471.

Elmqvist, T., Rainey, W.E., Pierson, E.D. \& Cox, P.A. (1994) Effects of tropical cyclones Ofa and Val on the structure of a Samoan lowland rain forest. Biotropica, 26, 384-391.

Esselstyn, J.A., Wiles, G.J. \& Amar, A. (2004) Habitat use of the Pacific sheath-tail bat (Emballonura semicaudata) on Aguiguan, Mariana Islands. Acta Chiropterologica, 6, 303-308.

FalanruW, M.V.C. (1988) On the status, reproductive biology and management of fruit bats on Yap. Micronesia, 21, 39-51.

Flannery, T.F. (1991) A new species of Pteralopex (Chiroptera: Pteropodidae) from Montane Guadalcanal, Solomon Islands. Records of the Australian Museum, 43, 123-129.

Flannery, T.F. (1995) Mammals of the South-West Pacific and Moluccan Islands. Reed Books, Chatswood, Australia.

Franklin, J., Drake, D.R., McConkey, K.R., Tonga, F. \& S Mith, L.B. (2004) The effects of Cyclone Waka on the structure of lowland tropical rain forest in Vava'u, Tonga. Journal of Tropical Ecology, 20, 409-420.

Fraser, H.R., Miles, A.C. \& Hay Smith, L. (2009) Surveys for the Pacific Sheath-tailed Bat in American Samoa (Technical Report 165). Unpublished Report. Pacific Cooperative Studies Unit, University of Hawai' i, Manoa, USA.

FritsCH, J.M. (1993) The hydrological effects of clearing tropical rain forest and of the implementation of alternative land uses.

International Association of Hydrological Sciences Publications, 216, 53-66.

Fuitita, M.S. \& Tuttle, M.D. (1991) Flying foxes (Chiropters: Pteropodidae): threatened animals of key ecological and economic importance. Conservation Biology, 5, 455-463.

Gilbert, T. (1984) Limestone and volcanic caves of the Fiji Islands. Transactions of the British Cave Research Association, 11, 105-118.

Gorresen, M.P., Bonaccorso, F.J. \& Pinzari, C.A. (2009) Habitat occupancy and detection of the Pacific sheath-tailed bat (Emballonura semicaudata) on Aguiguan, Commonwealth of the Northern Mariana Islands. Acta Chiropterologica, 11, 331-341.

Grant, G.S., Banack, S.A. \& Trail, P. (1994) Decline of the sheath-tailed bat Emballonura semicaudata (Chrioptera: Emballonuridae) on American Samoa. Micronesica, 27, 133-137.

Grant, G.S., Craig, P. \& Trail, P. (1997) Cyclone-induced shift in foraging behaviour in flying foxes in American Samoa. Biotropica, 2, 224-228.

Helgen, K.M. (2005) Systematics of the Pacific monkey-faced bats (Chiroptera: Pteropodidae), with a new species of Pteralopex and a new Fijian genus. Systematics and Biodiversity, 3, 433-453.

Helgen, K.M. \& Flannery, T.F. (2002) Distribution of the endangered Pacific sheathtail bat Emballonura semicaudata. Australian Mammalogy, 24, 209-212.

Hill, J.E. \& BeCKon, W.N. (1978) A new species of Pteralopex Thomas 1888 (Chiroptera Pteropodidae) from the Fiji Islands. Bulletin of the British Museum (Natural History) Zoological Series, $34,65-82$. 
Humphrey, S.R. \& Kunz, T.H. (1976) Ecology of a pleistocene relict, the western big-eared bat (Plecotus townsendii), in the southern Great Plains. Journal of Mammalogy, $57,470-494$.

Hutson, A.M., Mickleburgh, S.P., \& Racey, P.A. (2001) Microchiropteran Bats: Global Status Survey and Conservation Action Plan. IUCN/SSC Chiroptera Specialist Group, Gland, Switzerland.

Ingleby, S. \& Flannery, T. (1991) A Survey of the Mammals of Fiji: Report to the Government of Fiji. Unpublished Report. Australian Museum in collaboration with the National Trust of Fiji and the Ministry of Primary Industries, Suva, Fiji.

IUCN (2012a) The IUCN Red List of Threatened Species v. 2012.1. Http://www.iucnredlist.org [accessed 15 October 2012]

IUCN (2012b) IUCN Red List Categories and Criteria v. 3.1. Http://jr.iucnredlist.org/documents/redlist_cats_crit_en.pdf [accessed 15 October 2010].

Jones, K.E., Barlow, K.E., Vaughan, N., Rodríguez-Durán, A. \& GANNON, M.R. (2001) Short-term impacts of extreme environmental disturbance on the bats of Puerto Rico. Animal Conservation, 4, 59-66.

Kalko, E.K.V. \& Handley, Jr, C.O. (2001) Neotropical bats in the canopy: diversity, community structure, and implications for conservation. Plant Ecology, 153, 319-333.

Koopman, K.F. (1997) The subspecies of Emballonura semicaudata (Chiroptera: Emballonuridae). Journal of Mammalogy, 78, 358-360.

Koopman, K.F. \& Steadman, D.W. (1995) Extinction and biogeography of bats on 'Eua, Kingdom of Tonga. American Museum Novitates, 3125, 1-13.

LAVAL, R.K. (2004) Impact of global warming and locally changing climate on tropical cloud forest bats. Journal of Mammalogy, 85, 237-244.

Lees, A. (2007) Review and Analysis of Fiji's Conservation Sector. Final Report. The Austral Foundation, Waitakere City. Http://www. australfoundation.org/uploads/9/8/3/5/9835787/final_report_pdf_ lees.pdf [accessed 8 October 2012].

LEMKe, T.O. (1986) Distribution and status of the sheath-tailed bat (Emballonura semicaudata) in the Mariana Islands. Journal of Mammalogy, 67, 743-746.

Macedru, K. (2010) Report on a Preliminary Cave Inventory, Taveuni, Fiji Islands. Unpublished Report. NatureFiji-MareqetiViti, Suva, Fiji.

Macedru, K. \& Moce, K. (2011) Report on a Visit to the Fijian Free-tailed Bat (Tadarida bregullae) Cave at Nakanacagi, Macuata, Vanua Levu. Unpublished Report. NatureFiji-MareqetiViti, Suva, Fiji.

McConkey, K.R. \& Drake, D.R. (2002) Extinct pigeons and declining bat populations: are large seeds still being dispersed in the tropical Pacific? In Frugivory and Seed Dispersal: Ecological, Evolutionary and Conservation Perspectives (eds D.J. Levey, W.R. Silva \& M. Galetti), pp. 381-396. CAB International, Wallingford, UK.

McConkey, K.R. \& Drake, D.R. (2006) Flying foxes cease to function as seed dispersers long before they become rare. Ecology, 87, 271-276.

McConkey, K.R., Drake, D.R., Franklin, J. \& Tonga, F. (2004) Effects of Cyclone Waka on flying foxes (Pteropus tonganus) in the Vava'u Islands of Tonga. Journal of Tropical Ecology, 20, 555-561.

McCracken, G.F. (1986) Why are we losing our Mexican free-tailed bats? Bats, 3, 1-2.

McCracken, G.F. (1988) Who's endangered and what can we do? Bats, 6, 5-9.

Mickleburgh, S.P., Hutson, A.M. \& Racey, P.A. (1992) Old World Fruit-Bats - An Action Plan for their Conservation. IUCN, Gland, Switzerland.
Mickleburgh, S.P., Hutson, A.M. \& Racey, P.A. (2002) A review of the global conservation status of bats. Oryx, $36,18-34$

Mohr, C.E. (1972) The status of threatened species of cave-dwelling bats. National Speleological Society Bulletin, 34, 33-47.

NatureFiji-MareqetiViti (2012) NatureFiji-MareqetiViti Newsletter 13 (May 2012). NatureFiji-MareqetiViti, Suva, Fiji.

Olson, D., Farley, L., Patrick, A., Watling, D., Tuiwawa, M., Masibalavu, V. et al. (2009) Priority forests for conservation in Fiji: landscapes, hotspots and ecological processes. Oryx, 44, $57-70$.

Palmeirim, J.M., Champion, A., Naikatini, A., Niukula, J., Tuinawa, M., Fisher, M. et al. (2005) Distribution, Status and Conservation of the Bats of the Fiji Islands. Unpublished Report. University of the South Pacific, Fauna \& Flora International, and University of Lisbon, Suva, Fiji.

Palmeirim, J.M., Champion, A., Naikatini, A., Niukula, J., Tuiwawa, M., Fisher, M. et al. (2007) Distribution, status and conservation of the bats of the Fiji Islands. Oryx, $41,509-519$.

Perez, G.S.A. (1972) Observations of Guam bats. Micronesica, $8,141-149$.

Pierson, E.D., Elmqvist, T., Rainey, W.E. \& Cox, P.A. (1996) Effects of tropical cyclonic storms on flying fox populations on the South Pacific islands of Samoa. Conservation Biology, $10,438-451$.

Rinke, D.R. (1991) Birds of 'Ata and Late, and additional notes on the avifauna of Niuafo'ou, Kingdom of Tonga. Notornis, 38, 131-151.

SCanlon, A.T. (2009a) Survey for the Fiji Flying Fox (Mirimiri acrodonta) on Des Voeux Peak, Taveuni 2009. Unpublished Report. NatureFiji-MareqetiViti and University of South Australia, Suva, Fiji.

SCANLON, A.T. (2009b) The long-tailed flying fox (Notopteris macdonaldi) on Viti Levu, Fiji. Australasian Bat Society Newsletter, $32,17-19$.

Still, C.J., Foster, P.N. \& Schneider, S.H. (1999) Simulating the effects of climate change on tropical montane cloud forests. Nature, 398, 608-610.

Tarburton, M.K. (2002) Demise of the Polynesian sheathtailed bat Emballonura semicaudata in Samoa. Micronesica, 34, 105-108.

Tuiwawa, M. (1999) Floristic Survey of the Native Forest Catchment in Cakaudrove Province, Vanua Levu Fiji. Unpublished Report. University of the South Pacific, Suva, Fiji.

Tuttle, M.D. (1979) Status, causes or decline, and management of endangered gray bats. Journal of Wildlife Management, 43, 1-17.

Watling, D. \& Pernetta, J.C. (1978) Limestone caves in the Sigatoka Valley, Viti Levu, Fiji. Studies in Speleology, 3, 78-86.

Wiles, G.J. (1987) The status of fruit bats on Guam. Pacific Science, $41,148-157$.

Wiles, G.L., O’Shea, T.J., Worthington, D.J., Esselstyn, J.A. \& VALDEZ, E.W. (2011) Status and natural history of Emballonura semicaudata rotensis on Aguiguan, Mariana Islands. Acta Chiropterologica, 13, 299-309.

Wilson, D.E. \& Engbring, J. (1992) The flying foxes Pteropus samoensis and Pteropus tonganus: status in Fiji and Samoa. In Pacific Island Flying Foxes: Proceedings of an International Conservation Conference (eds D.E. Wilson \& G.L. Graham), pp. 74-101. Biological Report 9o. Fish and Wildlife Service, Washington, USA.

Wilson, D.E. \& Graham, G.L. (eds) (1992) Pacific Island Flying Foxes: Proceedings of an International Conservation Conference. 
Biological Report 90, pp. 1-174. Fish and Wildlife Service, Washington, USA.

Wodzicki, K. \& Felten, H. (1975) The peka, or fruit bat (Pteropus tonganus tonganus) (Mammalia, Chiroptera), of Niue Island, South Pacific. Pacific Science, 29, 131-138.

Wodzicki, K. \& Felten, H. (1980) Fruit bats of the genus Pteropus from the islands of Rarotonga and Mangaia, Cook Islands, Pacific Islands. Senckenbergiana Biologica, 61, 143-151.

ZuG, G.R., Springer, V.G., Williams, J.T. \& Johnson, D.G. (1988) The vertebrates of Rotuma and surrounding waters. Atoll Research Bulletin, 316, 1-25.

\section{Biographical sketches}

Annette Scanlon is interested in bat ecology and conservation in Australasia. She and Sophie Petit continue to support bat research and conservation in Fiji. So phie Petit continues her long-term research on bat-cactus interactions in the Caribbean and also works on the ecology and conservation of other plants and animals in Fiji and Australia. She is particularly interested in pollination, nectar, ethics, shelter ecology, and mammalogy. GuY Bottroff is interested in technical and ecological sciences. His rare photographs of M. acrodonta have been used widely in educational and promotional material. 